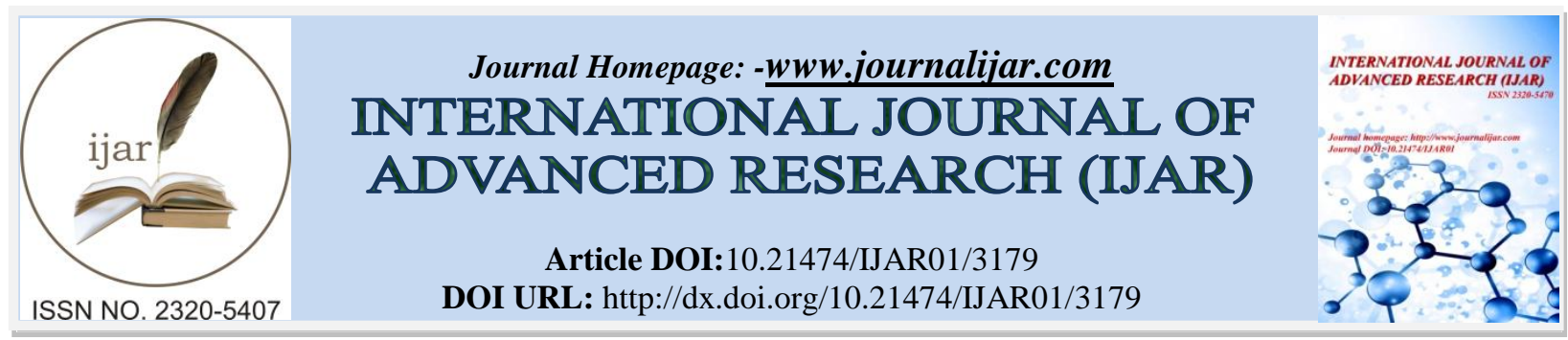

RESEARCH ARTICLE

\title{
PHYTOCHEMISTRY OF THREE INDIAN VARIETIES OFPUNICAGRANATUM AND VITAMIN-C STUDY BY HPLC TECHNIQUE
}

\section{Pavan C. Akkiraju ${ }^{1 *}$, Harshad S. Tambe ${ }^{1}$, Dipeeka D. Suryawanshi ${ }^{1}$, Srilakshmi Mamillapalli ${ }^{2}$ and Aparna J. Jawakekar'.}

1. Department of Biotechnology, P.V.P. College of Arts, Science \& Commerce, Pravaranagar, Loni, Ahmednagar (Dt.), Maharashtra.

2. Department of Pharmacy, Sarada College of Pharmaceutical Sciences, Kondakavuru, Narasarao pet, Guntur, (Dt.),A.P., India.

\section{Manuscript Info}

Manuscript History

Received: 15 Decmber 2016

Final Accepted: 03 January 2017

Published: February 2017

Key words:-

Pomegranate, Ascorbic acid, HPLC,

Exocarp, Mesocarp, Punicagranatum

\section{Abstract}

Three Indian pomegranate varieties with different physiological properties have been studied for their phytochemistry and ascorbic acid content. Local varieties of Punicagranatum L.namelyBhagwa, Ganesha andMridula were selected for analysis. The three parts of pomegranate viz. exocarp, mesocarp and seeds were separately processed as methanol extractions for various phytochemicals and HPLC analysis for Vitamin-C content. Flavonoids were found absent in the seeds of three varieties, whereas they were present in the exocarp and mesocarp of the same. On other hand, tannins were present in the seeds and absent in the exocarp and mesocarp of all varieties. Phycobilins were absent in all parts of Ganesha and mesocarp of Mridula. Out of all varieties, the mesocarp of Ganesha has high content of ascorbic acid with an area of $90.14 \%$ with a TP content of $4784.9 \mu \mathrm{g} / \mathrm{mg}$ and TF content of $1.6364 \mu \mathrm{g} / \mathrm{mg}$. Out of three varieties, exocarp, mesocarp and seeds of Ganesha resulted with more ascorbic acid content.

Copy Right, IJAR, 2017,. All rights reserved.

\section{Introduction:-}

A multitude of organic molecules or phytochemicals, generally referred as secondary metabolites are synthesized by vascular plants. These phenolic compounds are synthesized during plant development and are plays vital roles in the plant life cycle (Stalikas, 2007). Based on metabolic utilization, the plant produces primary constituents which include sugars, proteins and chlorophyll, whereas secondary constituents include alkaloids, steroids, terpenoids, etc. (Dhawale, 2013).Various fruits and vegetables have been confirmed for their phytochemical properties which include oranges and green fruits and vegetables (carotenoids); Apples, citrus fruits, onions, soybeans and products (flavonoids); Green tea, wine, grapes, berries, whole grains and peanuts (Polyphenols); Cherries, citrus fruits (Terpenes). Punicagranatumis a fruit, highly grows in Mediterranean regions under drought conditions (ChakrabortyManodeepet al. 2012). Pomegranates also showed many medicinal properties ranging from reduced oxidative stress, platelet aggregation (Aviramet al. 2000), antioxidant and antibacterial (Negi and Jayaprakasha, 2003) and antiviral (Zhang et al. 1995) activities.

Pomegranate can be separated into three major parts: peel, which includes exocarp,mesocarpandthe edible portion, Seeds. The peel of pomegranates contains good levels of phenolic compounds including tannins and flavonoids 
(Zhao et al. 2014). The edible plant parts are juice, pulp and seeds, which constitute around 65-75\% of total fruit weight (Tehranifaretal., 2010). The taste of the juice and seeds vary among different varieties of pomegranate. The taste may be sweet, sour or sweet-sour. However, these portions are rich in sugars, minerals and various phenolic constituents (Mansour et al. 2014).

The present study aimed to study various phytochemical compounds present in the exocarp, mesocarp and seeds of three varieties of pomegranates: Bhagwa, Ganesha and Mridula. The main objectives of the study include to identify the phytochemical constituents present in all the parts of the three varieties and to analyze ascorbic acid content from the same.

\section{Materials \&Methods:-}

Twenty individual fruits from each variety were collected randomly from the local markets of Loni, Maharashtra seperately to study the phytochemistry. Bhagwa is a fruit with orange-red fruit having peach-red colored seeds with sweet taste. Ganesha is a yellowish fruit with soft and pink colored seeds having sour-sweet taste. Mridula is a red fruit with red seeds and sour-sweet taste (Fig. 1).

The fruits were collected seperately in wooden boxes and stored at the Laboratory of Biotechnology, P.V.P. College, Loni. The exocarp, mesocarp and seeds were isolated manually and they were dried in hot air oven at $50^{\circ} \mathrm{C}$ until they dried completely. The dried plant materials were grinded by using a house-hold mixer grinder. The Soxhlet procedure for methanol extraction is performed (Akkirajuet al. 2016) and collected the extracted powder separately from each part of three varieties of pomegranates (Fig. 1). These powders are then subjected to various studies of primary Phytochemical compounds viz. test for saponins, proteins, carbohydrates, amino acids, glycosides and secondary Phytochemical compounds viz. test for alkaloids, flavonoids, vitamin-C, anthraquinones, phycobilins and tannins. The presence or absence of the mentioned compounds and HPLC analysis for ascorbic acid were performed according to Akkirajuet al. (2016).

\section{Results:-}

The triplicates of tests perfomed for the identification of different phytochemicals was tabulated (Table1). The saponins, alkaloid, carbohydrates and ascorbic acid were found present in all the parts of Bhagwa, Ganesha and Mridula. Glycosides, proteins, amino acids and anthraquinones are absent in all the parts of all three varieties. The flavonoids were present in exocarp and mesocarp of three varieties, but found absent in the seeds. The tannins were absent in the exocarp and mesocarp of all three varieties and resulted positive in seeds. Phycobilins were positive in all the parts of Bhagwa and negative in all parts of Ganesha. In Mridula, exocarp and seeds have phycobilins, but mesocaro does not possess them.

Ascorbic acid analysis by HPLC was performed and the results were obtained (Fig. 2a, b, c; Table 2). The same has revealed ascorbic acid peaks and compared with the standard. The chromatogram for the exocarp, mesocarp and seeds showed peaks confirming the quantity of Vitamin-C. The mesocarp of Ganesha has showed the peak within a retention time of $3.9167 \mathrm{~min}$, whereas the exocarp of Mridula showed the highest RT (4.3833 min.). The maximum peak area was identified for the exocarp of Mridula with an area of $84335.227 \mathrm{mV}^{*} \mathrm{~s}$ with an area\% of $81.79 \%$, where it showed a significant TP value of 456.1 and TF value of 0.5469 . The least area peak area was observed for the seeds of Ganesha with an area of $1144.852 \mathrm{mV}^{*}$ s with an area\% of $40.72 \%$. In respect to area\%, Mesocarp has a maximum area\% of $90.14 \%$ and minimum was for the seeds of Mridula with $30.17 \%$. The maximum number of Theoretical Plates (TP) was observed for the mesocarp of Ganesha with 4784.9 and the minimum was found in the exocarp of Mridula with a TP of 456.1. The exocarp of Ganesha has a maximum TF value (1.75) and the same of Mridula has a minimum TF value (0.5469). 


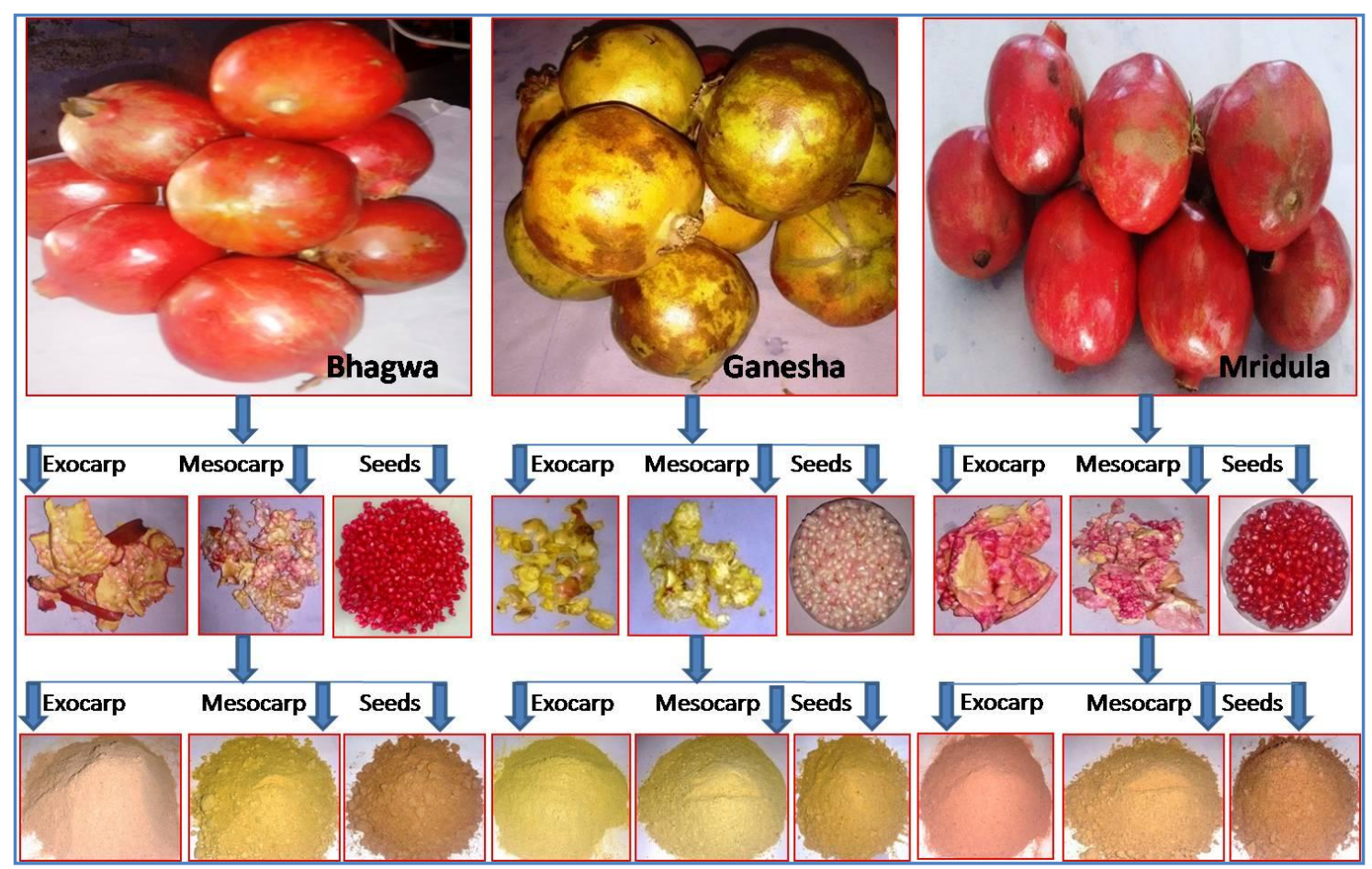

Figure 1:- Preparation of powders from exocarp, mesocarp and seeds of Bhagwa, Ganesha and Mridula.
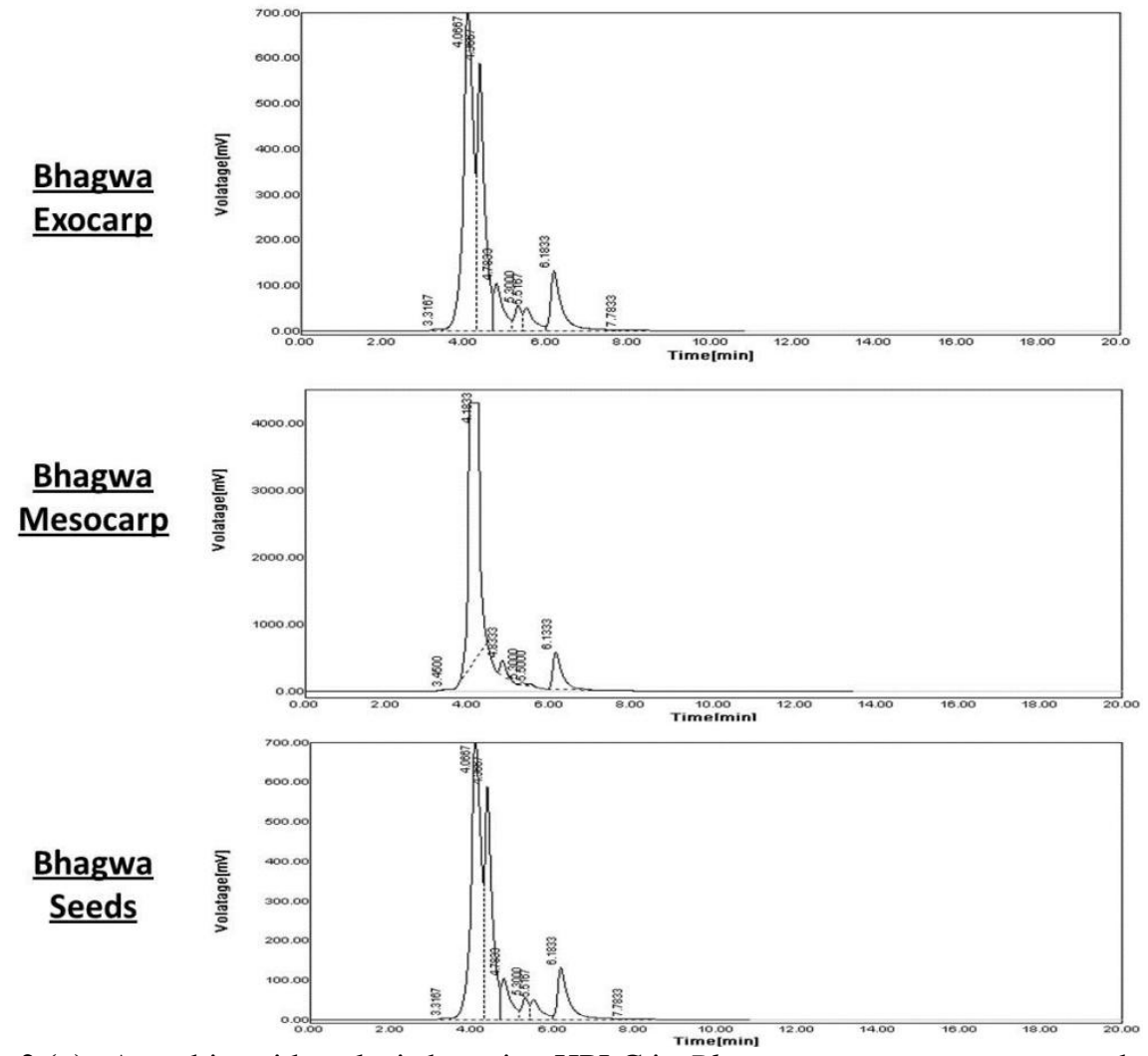

Figure 2 (a):-Ascorbic acid analysis by using HPLC in Bhagwa exocarp, mesocarp and seeds. 
Ganesha

Exocarp

Ganesha

Mesocarp

Ganesha

Seeds
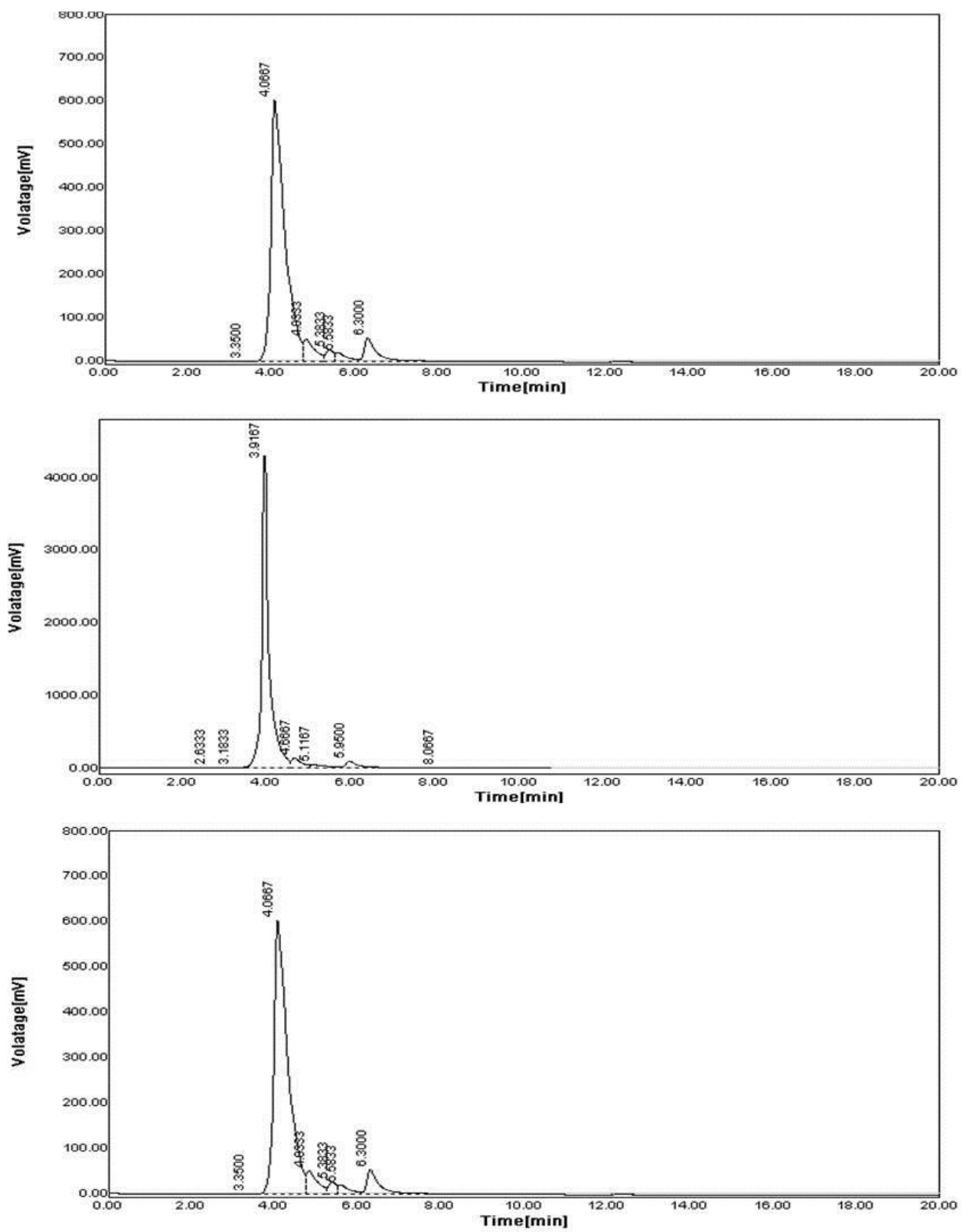

Figure 2 (b):- Ascorbic acid analysis by using HPLC in Ganesha exocarp, mesocarp and seeds. 


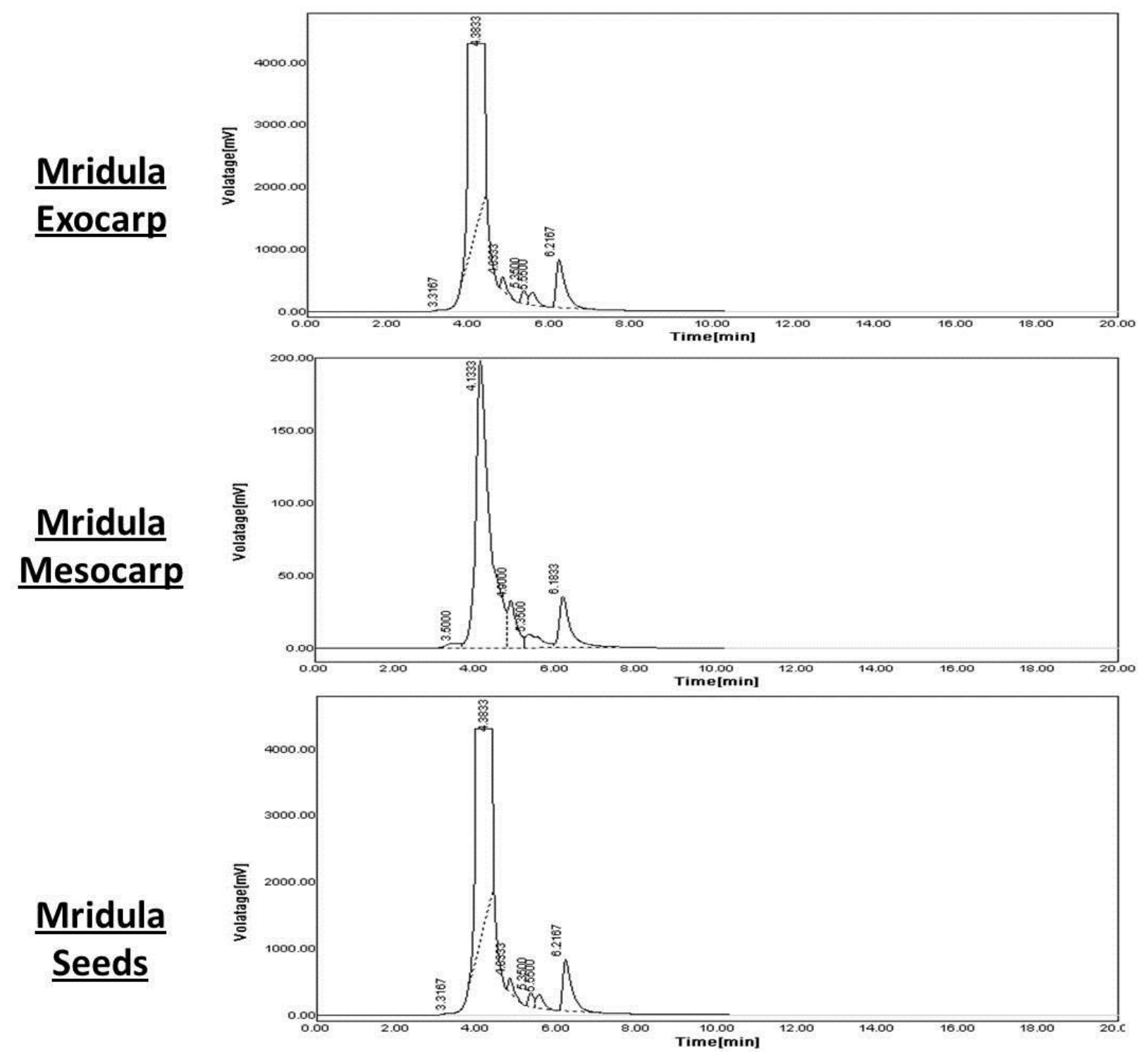

Figure 2 (c):-Ascorbic acid analysis by using HPLC in Mridula exocarp, mesocarp and seeds.

Table 1:-List of Phytochemicals tested and their presence or absence in different parts of pomegranates.

\begin{tabular}{|c|l|c|c|c|c|c|c|c|c|c|}
\hline \multirow{2}{*}{ S. No. } & \multirow{2}{*}{ Test Compound } & \multicolumn{3}{|c|}{ Bhagwa } & \multicolumn{3}{|c|}{ Ganesha } & \multicolumn{3}{c|}{ Mridula } \\
\cline { 3 - 11 } & & $\begin{array}{l}\text { Exo } \\
\text { Carp }\end{array}$ & $\begin{array}{l}\text { Meso } \\
\text { Carp }\end{array}$ & Seeds & $\begin{array}{l}\text { Exo } \\
\text { carp }\end{array}$ & $\begin{array}{l}\text { Meso } \\
\text { carp }\end{array}$ & Seeds & $\begin{array}{l}\text { Exo } \\
\text { carp }\end{array}$ & $\begin{array}{l}\text { Meso } \\
\text { carp }\end{array}$ & Seeds \\
\hline 1 & Saponins & + & + & + & + & + & + & + & + & + \\
\hline 2 & Flavonoids & + & + & - & + & + & - & + & + & - \\
\hline 3 & Glycosides & - & - & - & - & - & - & - & - & - \\
\hline 4 & Proteins & - & - & - & - & - & - & - & - & - \\
\hline 5 & Carbohydrates & + & + & + & + & + & + & + & + & + \\
\hline 6 & Alkaloids & + & + & + & + & + & + & + & + & + \\
\hline 7 & Amino acids & - & - & - & - & - & - & - & - & - \\
\hline 8 & Tannins & - & - & + & - & - & + & - & - & + \\
\hline 9 & Anthraquinones & - & - & - & - & - & - & - & - & - \\
\hline 10 & Phycobilins & + & + & + & - & - & - & + & - & + \\
\hline 11 & Ascorbic acid & + & + & + & + & + & + & + & + & + \\
\hline
\end{tabular}


Table 2:-Ascorbic acid analysis: RT- Retention time; TP- Theoretical Plates; TF- Tailing Factor

\begin{tabular}{|l|l|c|c|c|c|c|}
\hline & Name & RT[min] & Area $[\mathbf{m V}$ :s] & Area\% & TP & TF \\
\hline Exocarp & Bhagwa & 4.0667 & 12075.139 & 47.28 & 1018.9 & 1.2500 \\
\hline & Ganesha & 4.0667 & 14123.877 & 82.83 & 825.3 & 1.7500 \\
\hline & Mridula & 4.3833 & 84335.227 & 81.79 & 456.1 & 0.5469 \\
\hline Mesocarp & Bhagwa & 4.1833 & 75550.063 & 86.17 & 967.7 & 0.8947 \\
\hline & Ganesha & 3.9167 & 52225.969 & 90.14 & 4784.9 & 1.6364 \\
\hline Seeds & Mridula & 4.1333 & 4745.440 & 75.52 & 944.7 & 1.5000 \\
\hline & Bhagwa & 4.1667 & 2462.467 & 33.71 & 475.4 & 1.0000 \\
\hline & Ganesha & 4.1500 & 1144.852 & 40.72 & 596.9 & 1.0000 \\
\hline & Mridula & 4.1833 & 3911.646 & 30.17 & 479.2 & 1.0909 \\
\hline
\end{tabular}

\section{Discussion:-}

Evaluation of total phenolic contents, antioxidant activities and presence of vitamins in pomegranate were previously reported and discussed. Elfalleh et al. (2012) showed that the methanolic extracts to study alkaloids, flavonoids and tannins were suitable for phytochemical screening, which is supported by this current study. However, we found the difference among three varieties of pomegranates in respect to flavonoids and tannins. Alkaloids were present in all the varieties and studied through methanol extractions. We found that flavonoids and tannins were oppositely present among the varieties. In all the varieties, exocarp and mesocarp contained flavonoids, but seeds contained only tannins. Bhandari et al. (2012), while performing the phytochemical screening with peel and seeds, revealed the presence of glycosides in peel (Chloroform) and seeds (Ethanol). However, in the current study, we found no glycoside content in any part of any variety. This may be due to methanol extraction. The same authors reported the absence of flavonoids in seeds, which is supported by our study. In respect to saponins and alkaloids, we observed them in all varities and their parts, where as, these authors were not able to found the same in peels. These authors reported tannins in peels, where as we found tannins only in seeds. Chebaibiet al. (2013) showed the absence of alkaloids in peel extracts, where as our results showed alkaloids presence in the peel extracts. They found tannins and glycosides in peels, where as we found absence of the both in peels.

Anahitaet al. (2015) evaluated antioxidant vitamin i.e. ascorbic acid from pomegranate juice and seed and concluded that a combination of both seed-juice have high phenolic compounds and vitamin-C. In the current study, the mesocarp of Ganesha showed high content of ascorbic acid (90.14\%). It indicates that, mesocarp can be a complementary source for vitamin-c supplement.

\section{Conclusion:-}

The presence of various phytochemicals in pomegranate can promote the essential constituents in alimentary purposes. We found variation in phytochemical constituents among different varieties of pomegranates available in India. We found that the seeds of these varieties does not contain flavonoids, but are rich of tannins. These varieties showed absence of glycosides. Neither a single variety nor any part of these varieties showed glycoside's presence. We also found alkaloids in seeds. In respect to ascorbic acid, out of all the parts and varieties, the mesocarp of Ganesha showed high content of ascorbic acid.

\section{Acknowledgements:-}

The authors are thankful to P.V.P. College of Arts, Science and Commerce, Loni, for providing the essential facilities to conduct the laboratory experiments. 


\section{References:-}

1. Akkiraju P.C., Suryawanshi, D.D., Jawakekar, A.J., Harshad, S.T., Mamillapalli, S.L. (2016). Phytochemical analysis and HPLC study of vitamin-C from Punicagranatum L. Aarakta variety of India, Journal of Medicinal Plants Studies, 4(6), 09-12.

2. Anahita, A., Asmah, R. and Fauziah, O. (2015). Evaluation of total phenolic content, total antioxidant activity, and antioxidant vitamin composition of pomegranate seed and juice. International Food Research Journal, 22(3), 1212-1217.

3. Aviram, M., Dornfeld, L., Rosenblat, M., Volkova, N., Kaplan, M., Coleman, R., Hayek, T., Presser, D., Fuhrman, B.(2000). Pomegranate juice consumption reduces oxidative stress, atherogenic modifications to LDL, and platelet aggregation: studies in humans and in atherosclerotic apolipoprotein E-deficient mice. American Journal of Clinical Nutrition 71 (5), 1062-1076.

4. Bhandary, S.K., Suchetha N., Bhat, V.S., Sharmila, K.P., Bekal. M.P. (2012). Preliminary phytochemical screening of various extracts of Punicagranatum peel, whole fruit and seeds. Nitte University Journal of Health Science, 2 (4), 34-38.

5. Chebaibi, A., Filali, F.R. (2013). Bactericidal activity and phytochemical screening of Moroccan pomegranate (PunicagranatumLinn.) peel aqueous extracts. Journal of Medicinal Plant Research, 7 (14), 887-891.

6. Dhawale, P.G. (2013). Phytochemical Analysis of Eight Medicinal Plants from Amravati District (MS) India. International Journal of Scientific and research Publications,3(1), 1-3.

7. Elfalleh, W., Hannachi, H., Tlili, N., Yahia, Y., Nasri, N. and Ferchichi, A. (2012). Total phenolic contents and antioxidant activities of pomegranate peel, seed, leaf and flower. Journal of Medicinal Plants Research, 6, 4724-4730.

8. Garachh, D., Patel, A., Chakraborty M. Kamath J.V. (2012). Phytochemical and Pharmacological Profile of Punicagranatum: An overview. International Research Journal of Pharmacy, 3 (2), 65-68.

9. Mansour, E., Abdennaceur, B. K., Yahya, L.B., Mabrouka A.,Khouloud B., Ferchichi, A. (2014).

10. Fiber content and quality of pomegranate (PunicagranatumL.) Cultivated in a Coastal Oasis. International Journal of Current Microbiology and Applied Sciences, 3 (2), 915-924

11. Negi, P.S., Jayaprakasha, G.K.(2003). Antioxidant and antibacterial activities of Punicagranatum peel extracts. JFS - Food Microbiology and Safety 68 (4), 1473-1477.

12. Stalikas, C.D. (2007). Extraction, separation, and detection methods forphenolic acids and flavonoids. Journal of Separation Science, 30, $3268-3295$.

13. Zhang, J., Zhan, B., Yao, X., Gao, Y., Shong, J. (1995). Antiviral activity of tannin from the percarp of Punicagranatum L. against genital herpes virus in vitro. ZhongguoZhong Yao ZaZhi 20 (9), 556-558.

14. Zhao, X., Yuan, Z., Fang, Y., Yin, Y., Feng, L. (2014). Flavonols and Flavones changes in Pomegranate (Punicagranatum L.) fruit peel during fruit development. Journal of Agricultural Science and Technology. 16, 1649-1659. 